\title{
Relationship between white tea and adipose tissue metabolism: The importance and necessity of future research regarding the effect of white tea on fat oxidation, compared to other kinds of tea
}

\author{
$\underline{\text { Amir Hossein Ahmadi Hekmatikar }}$
}

\begin{abstract}
Obesity is a complex multifactorial disease. The worldwide prevalence of obesity has doubled since 1980 to an extent that nearly a third of the world's population is now classified as overweight or obese. On the other hand, sports scientists have suggested exercise for the prevention of further spread of this disease. In addition to exercise, the use of natural fat-burning supplements, such as green tea, has attracted a lot of attention during the recent years. However, the results of some domestic and foreign research have shown that fatburning potential of white tea is the same or superior to that of green tea. Therefore, it is suggested that researchers compare green and white tea in terms of their effects on obesity-related indicators.
\end{abstract}

Keywords: Fat oxidation, Green tea, White tea

Citation: Ahmadi Hekmatikar AH. [Relationship between white tea and adipose tissue metabolism: The importance and necessity of future research regarding the effect of white tea on fat oxidation, compared to other kinds of tea]. J Birjand Univ Med Sci. 2020; 27(4): 397-400. [Persian]

DOI http://doi.org/10.32592/JBirjandUnivMedSci.2020.27.4.109

Received: June 14, $2020 \quad$ Accepted: July 22, 2020

\footnotetext{
${ }^{1}$ Physical Education Department Faculty of Humanities, Tarbiat Modares University, Tehran, Iran

Corresponding author: Physical Education Department Faculty of Humanities,Tarbiat Modares University, Tehran, Iran Tel: +989919353001 


\section{ارتباط بين جاى سفيد و متابوليسم بافت جربى: اهميّت و ضرورت تحقيقات در آينده در زمينه تأثير

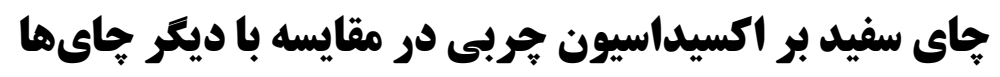

\section{امير حسين احمدى حكمتى كار}

\section{جككيله}

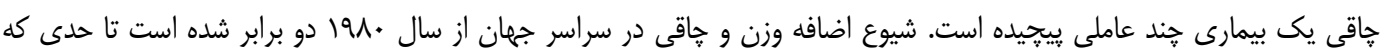

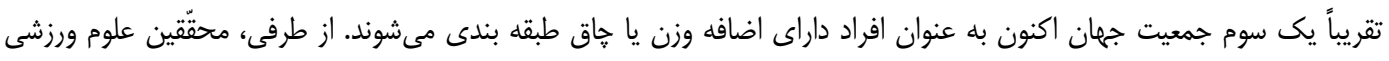

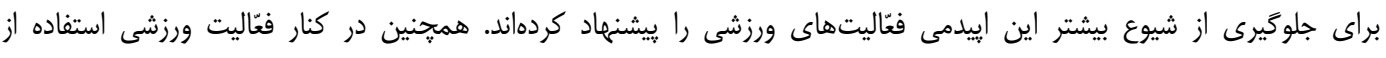

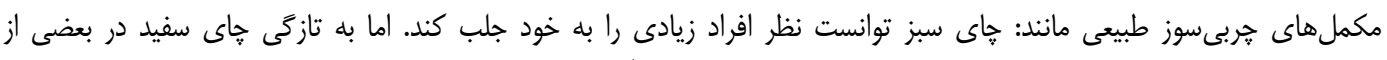

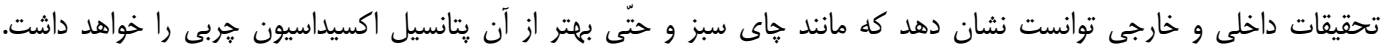

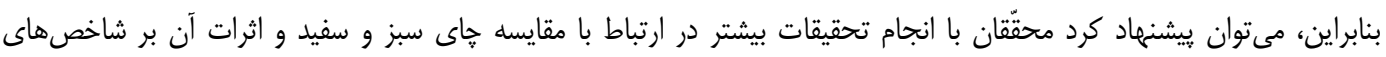

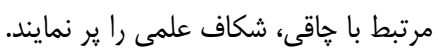

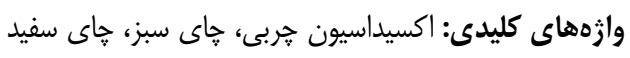

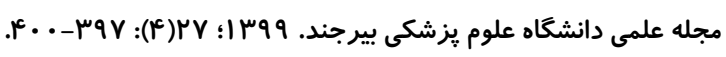

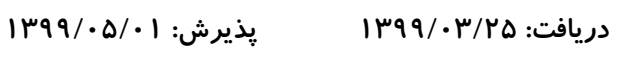


بررسى تفاوتهاى جاى سفيد با ديخر خاىها و تأثير اين خاىها بر

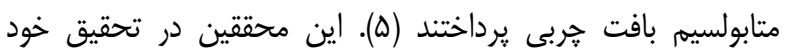

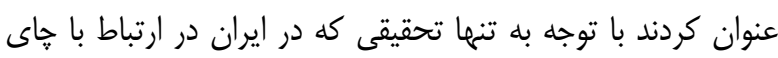

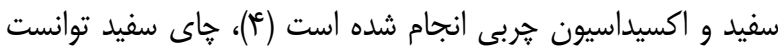

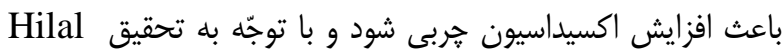

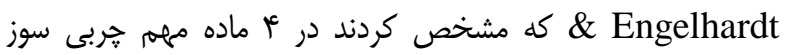

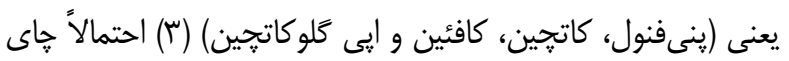

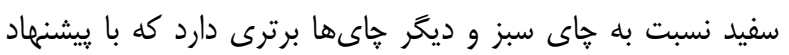

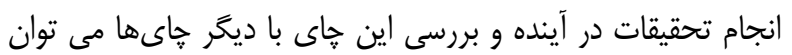

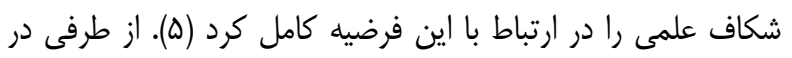

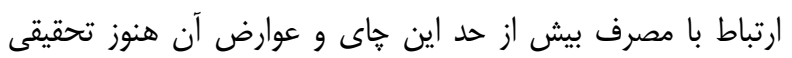

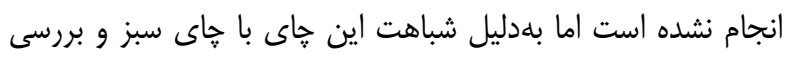
اثرات جانبى خاى سبز، مصرف بيش از حد اين خاى مئ تواند كافئين

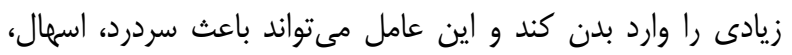

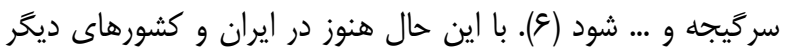

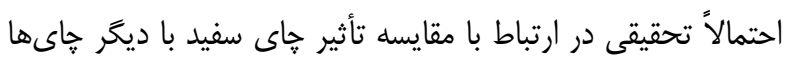

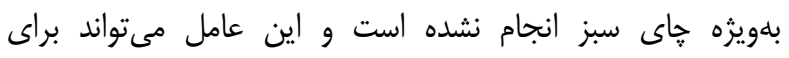

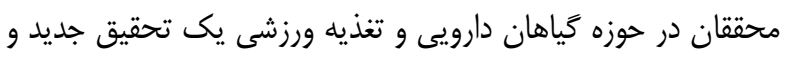

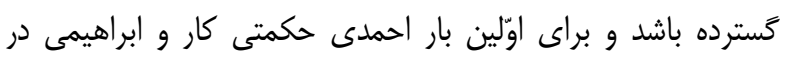

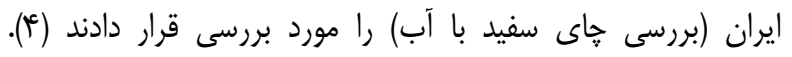
همجنين مشخص شده است كه خاى سفيد خواص آنتى اكسيدانى إنى

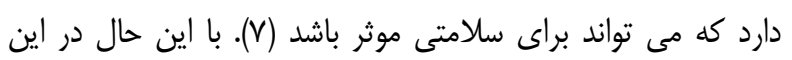

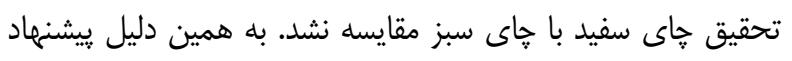

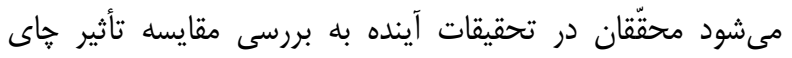

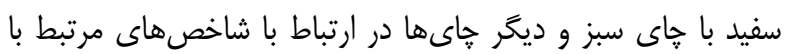

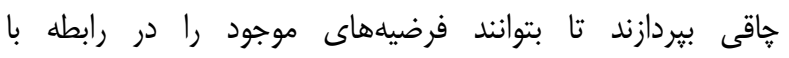
يتانسيلهاى خاى سفيد به افراد خاق ارائه دهند.

\section{سردبير محترم}

جاقى به تجمع بيش از حد جربى در بلن تفتله مىشود كه براى سلامتى بسيار مضر است (1). اين بيمارى عوارض بسيار زيادى

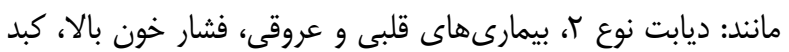

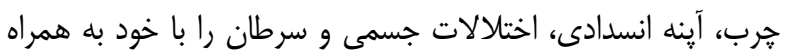

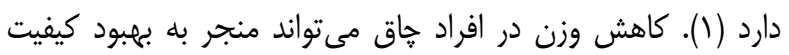
زندگىى، كاهش افسردگى، كاهش ير خورى و سلامت جسمانى آنها شود كه امروزه از طريق روشهاى مختلفى نظير جراحى، رعايت اهني

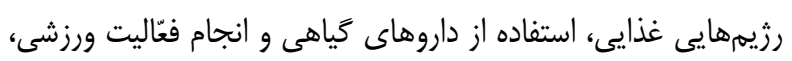

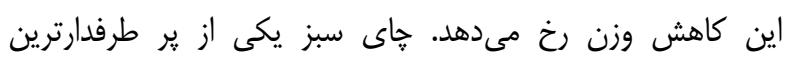

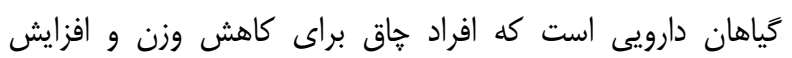

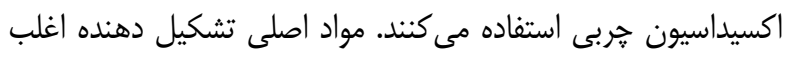

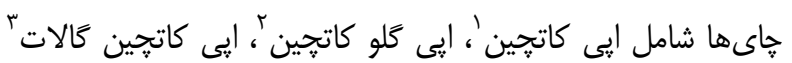

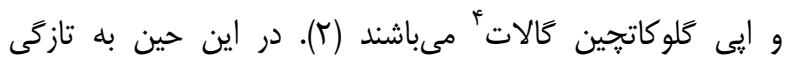

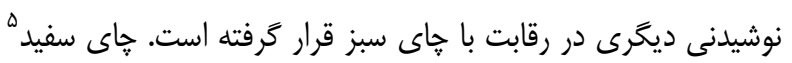

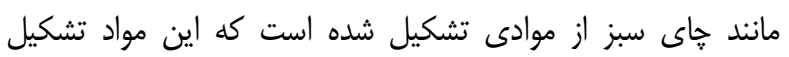

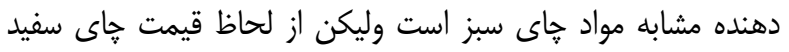
كرانتر از خاى هاى ديخر مى باشد (َّ). كزارش كردند كه ميزان مادّهاى Hilal \& Engelhardt

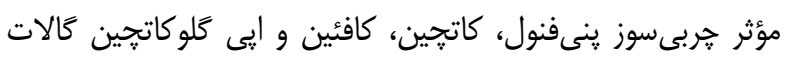

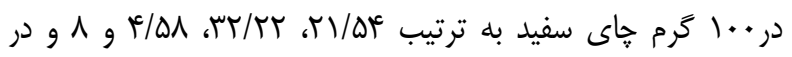

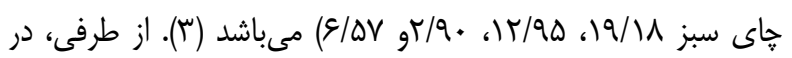
تحقيقى ديگر محققين تأثير مصرف خاى سفيد را بر اكسيداسيون جربى افراد جاق مورد بررسى قرار دادند و در نتايج خود عنوان كردند كه مصرف جاى سفيد يك ساعت قبل از فُّاليت ورزشى مى هوتواند باعث افزايش اكسيداسيون جربى در مردان جاق شود. در اين تحقيق

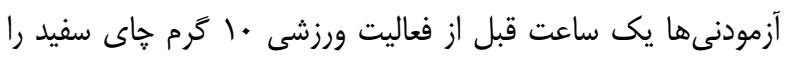

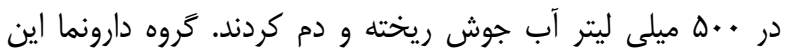
تحقيق گروه مصرف آب بود (أ). در يكى مطالعه مرورى محققين به لبه

\footnotetext{
${ }^{1}$ Epicatechin

${ }^{2}$ Epigallocatechin

${ }^{3}$ Epicatechingalat

${ }^{4}$ Epigallocatechingalat

${ }^{5}$ Camellia sinensis
} 


\section{منابع:}

1- Schetz M, De Jong A, Deane AM, Druml W, Hemelaar P, Pelosi P, et al. Obesity in the critically ill: a narrative review. Intensive Care Med. 2019; 45(6): 757-69. DOI: 10.1007/s00134-019-05594-1

2- Pastoriza S, Mesías M, Cabrera C, Rufián-Henares JA. Healthy properties of green and white teas: an update. Food Func. 2017; 8(8): 2650-62. DOI: 10.1039/c7fo00611j

3- Bandyopadhyay D, Chatterjee TK, Dasgupta A, Lourduraja J, Dastidar SG. In vitro and in vivo antimicrobial action of tea: the commonest beverage of Asia. Biol Pharm Bull. 2005; 28(11): 2125-7. DOI: 10.1248/bpb.28.2125.

4- Hilal Y, Engelhardt U. Characterisation of white tea-Comparison to green and black tea. Journal für Verbraucherschutz und Lebensmittelsicherheit. 2007; 2(4): 414-21. DOI: 10.1007/s00003-007-0250-3

5- Ahmadi Hekmatikar AH, Ebrahimi M. Substrate Oxidation Changes During Exercise After White Tea Consumption in Obese Men. Sport Physiol. 2019; 11(43): 141-50. DOI: 10.22089/SPJ.2019.7601.1933 [Persian]

6- Ahmadihekmatikar A, Ebrahimi M. Tea and Fat Burning in Sport: A Review of Available Evidence. J Neyshabur Univ Med Sci. 2019; 7 (4): 1-15. [Persian]

7- Dias T. White Tea (Camellia sinensis (L.)): an-tioxidant properties and beneficial health effects. Int J Food Sci Nutr Diet. 2013; 2(2): 19-26. DOI: 10.19070/2326-3350-130005. 